\title{
A new species of armored catfish Parotocinclus (Siluriformes: Loricariidae) from the rio Parnaíba basin, northeastern, Brazil
}

\author{
Telton P. A. Ramos ${ }^{1,2}$, Sergio M. Q. Lima ${ }^{1}$ and Robson T. da Costa Ramos ${ }^{2}$
}

Recent taxonomic studies indicated the presence of several undescribed species in the rio Parnaíba basin. Among those, a new species of Parotocinclus endemic of this drainage is herein described. It differs from most of its congeners, including the sympatric $P$. haroldoi and $P$. cearensis, by a vestigial or rudimentary adipose fin ( $v s$. conspicuous adipose fin). This character is also present in $P$. bidentatus and P. muriaensis (both from the rio Paraíba do Sul basin, southeastern Brazil), $P$. spilurus (rio Jaguaribe basin, northeastern Brazil), P. seridoensis (rio Piranhas-Açu basin, northeastern Brazil), P. halbothi (rios Trombetas and Marowijne basins, northern Brazil and Suriname) and P. dani (from rio Tapajós in Mato Grosso State, Brazil). The new species differs from these latter species mainly by the abdomen extensively covered by broad dermal plates. It also differs from $P$. haroldoi and $P$. cearensis by light bands between the snout tip and the nostrils.

Keywords: Caatinga and Cerrado ichthyofauna, Hypoptopomatinae, Maranhão-Piauí ecoregion, Taxonomy.

Estudos taxonômicos recentes indicaram a presença de várias espécies não descritas na bacia do rio Parnaíba. Dentre estas, uma nova espécie de Parotocinclus endêmica desta drenagem é aqui descrita. Ela difere da maioria dos seus congêneres, incluindo as simpátricas $P$. haroldoi e $P$. cearensis, por apresentar nadadeira adiposa vestigial ou rudimentar (vs. nadadeira adiposa desenvolvida). Este caráter também está presente em P. bidentatus e P. muriaensis (ambos do rio Paraíba do Sul, sudeste do Brasil), P. spilurus (bacia do rio Jaguaribe, nordeste do Brasil), P. seridoensis (bacia do rio Piranhas-Açu, nordeste do Brasil), P. halbothi (bacias dos rios Trombetas e Marowijne, norte do Brasil e no Suriname) e P. dani (do rio Tapajós no Estado do Mato Grosso, Brasil). A nova espécie difere destas principalmente pelo abdômen extensivamente coberto por placas dérmicas largas. Também difere de $P$. haroldoi e $P$. cearensis pela presença de faixas claras entre a ponta do focinho e as narinas.

Palavras-chave: Ecorregião Maranhão-Piauí, Hypoptopomatinae, Ictiofauna da Caatinga e Cerrado, Taxonomia.

\section{Introduction}

Parotocinclus Eigenmann \& Eigenmann is currently considered a polyphyletic genus (Gauger, Buckup, 2005; Lehmann, 2006; Lehmann et al., 2013; Martins et al., 2014). The genus is widely distributed in cis-andean South America, including the Orinoco, Amazon, Parnaíba and São Francisco river basins, the Atlantic coastal drainages of the Guianas, and the coastal rivers from Northeastern Brazilian states as well as the coastal rivers between the states of Espírito Santo and Santa Catarina (Garavello, 1977, 1988; Schaefer, 2003; Lehmann et al., 2015; Roxo et al., 2016).

The northeastern Brazil includes the highest species richness of the small armored catfishes Parotocinclus, with 12 of 30 nominal species (Ramos et al., 2016; Lehmann et al., 2015; Roxo et al., 2016). Five of these species were described by Garavello (1977, 1988): Parotocinclus cristatus Garavello, P. jimi Garavello and P. minutus Garavello, all from eastern coastal basins of Bahia State (Northeastern Mata Atlântica ecoregion, NMAE), P. cearensis Garavello from rio Acaraú and Choró basins, Ceará State (Mid-Northeastern Caatinga ecoregion, MNCE), and $P$. haroldoi Garavello from rio Parnaíba basin, Piauí State (Maranhão-Piauí ecoregion, MAPE). Ramos et al. (2014), when conducting a broad taxonomic study of the freshwater fishes of the Parnaíba drainage indicated several undescribed species, and also recorded $P$. cearensis, extending its distribution previously known only from the MNCE (Rosa et al., 2003).

At least six of species of Parotocinclus have vestigial or rudimentary adipose fin: $P$. bidentatus Gauger \& Buckup and P. muriaensis Gauger \& Buckup (both from the rio Paraíba do Sul basin, southeastern Brazil), P. halbothi Lehmann,

${ }^{1}$ Laboratório de Ictiologia e Sistemática Evolutiva, Departamento de Botânica e Zoologia, Universidade Federal do Rio Grande do Norte, Lagoa Nova, 59978-970 Natal, RN, Brazil. (TPAR) telton@gmail.com (corresponding author), (SMQL) smaialima@gmail.com

${ }^{2}$ Laboratório de Sistemática e Morfologia de Peixes, Departamento de Sistemática e Ecologia/CCEN, Universidade Federal da Paraíba, Campus I, 58059-900 João Pessoa, PB, Brazil. (RTCR) robtamar@gmail.com 
Lazzarotto \& Reis (rios Trombetas and Marowijne basins, northern Brazil and Suriname), P. seridoensis Ramos, BarrosNeto, Britski \& Lima (rio Piranhas-Açu basin, northeastern Brazil, MNCE), P. spilurus (Fowler) (rio Jaguaribe basin, northeastern Brazil, MNCE) (Ramos et al., 2016) and P. dani Roxo, Silva \& Oliveira (from rio Tapajós in Mato Grosso State, Brazil) (Roxo et al., 2016). The goal of the present paper is to describe a new species of Parotocinclus from the Parnaíba basin, which also shares this characteristic.

\section{Material and Methods}

Specimens were fixed in 10\% formalin neutralized with sodium tetraborate for approximately two weeks and then transferred to $70 \%$ ethanol. A few specimens were photographed in life in order to record coloration. Specimens were deposited in the fish collection of the Departamento de Sistemática e Ecologia of the Universidade Federal da Paraíba (UFPB), Departamento de Botânica e Zoologia of the Universidade Federal do Rio Grande do Norte (UFRN) and Museu de Zoologia da Universidade de São Paulo (MZUSP). Meristic and morphometric data were taken according to Hubbs, Lagler (2006) and Carvalho, Reis (2009), while counting of longitudinal plate series followed Britski, Garavello (2009). Measurements were taken with digital calipers, and recorded to tenths of millimeter. Measurements are presented as percentages of standard length (SL) or head length (HL). Meristic data ranges include all specimens available for study. Osteological examinations were performed on specimens cleared and double-stained for bone and cartilage (c\&s) according to the procedure of Taylor, Van Dyke (1985). Descriptions of color pattern were based on photographs of live individuals kept in aquaria just after collection.

\section{Results}

\section{Parotocinclus cabessadecuia, new species}

urn:1sid:zoobank.org:act:D27E518C-A68E-4863-B5F5AF5E 47D2E55E

(Figs. 1-2)

Parotocinclus sp. Ramos et al. (2014): 4 (species list).

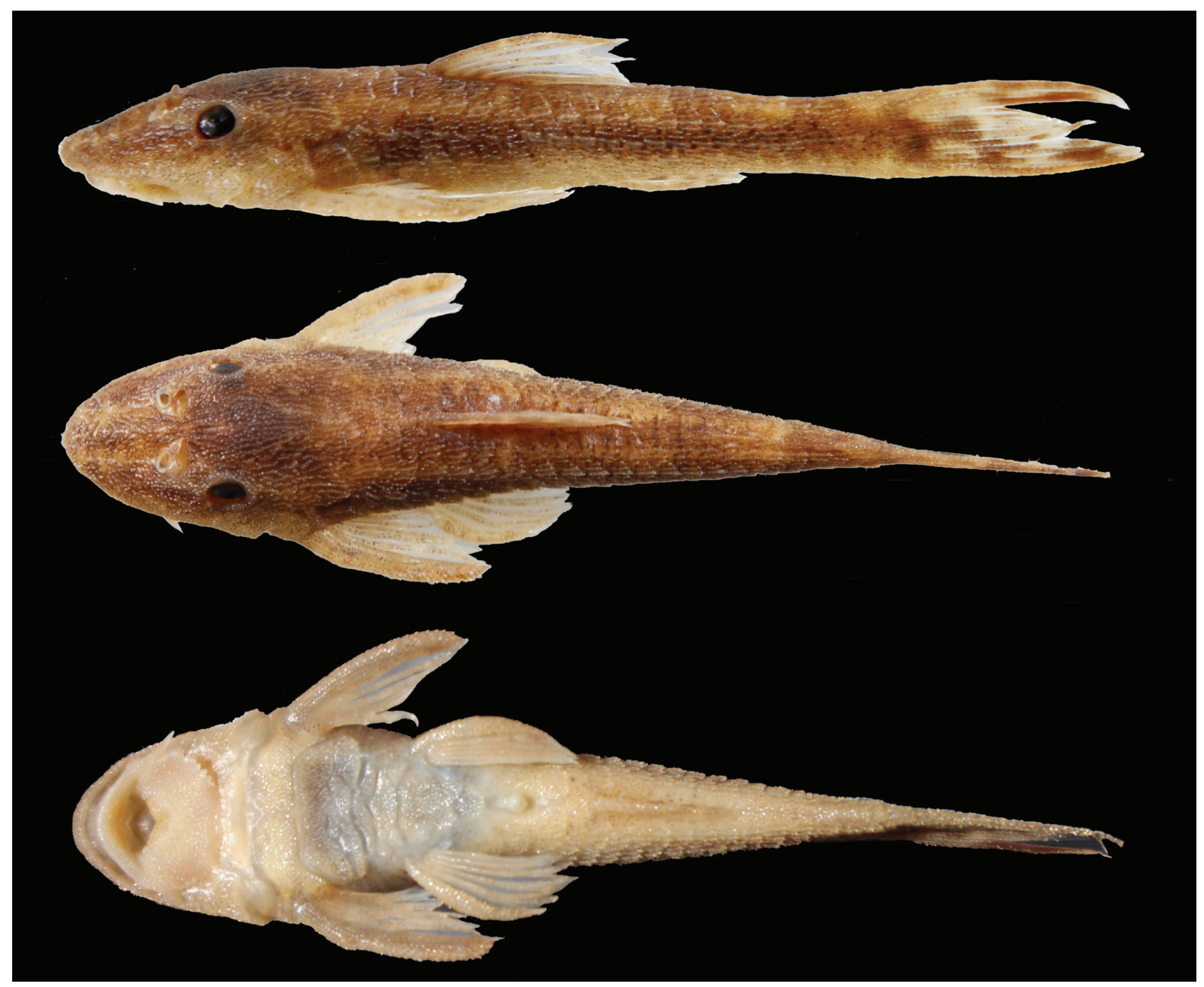

Fig. 1. Lateral, dorsal, and ventral views of Parotocinclus cabessadecuia, new species, holotype, UFPB 10029, $29.3 \mathrm{~mm}$ SL, female; Brazil, Piauí State, São Gonçalo do Gurgueia Municipality, rio Gurgueia, rio Parnaíba basin. 


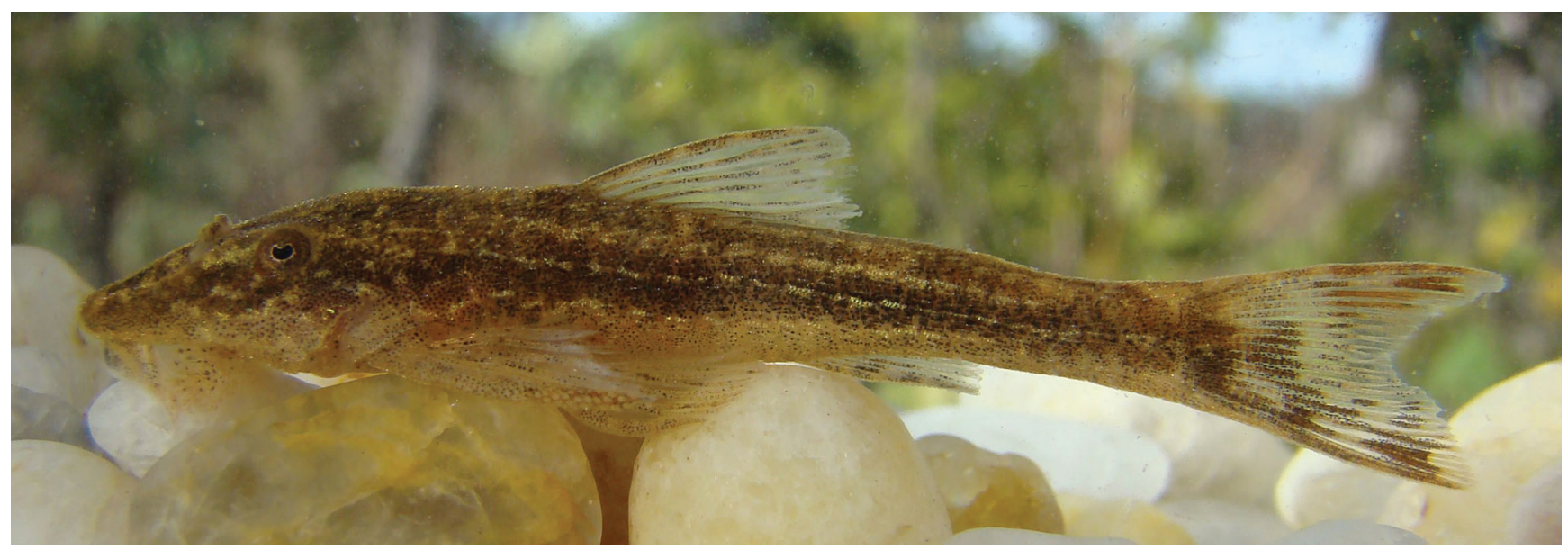

Fig. 2. Parotocinclus cabessadecuia, new species; live specimen just after collection, holotype.

Holotype. UFPB 10029, 29.3 mm SL, female, Brazil, Piauí, São Gonçalo do Gurgueia, rio Gurgueia, rio Parnaíba basin, $10^{\circ} 06$ '27.0”S 45²1'24.0”W, 19 Jun 2014, T. Ramos, L. Neto \& M. Germano.

Paratypes. All from Brazil. Piauí State. UFRN 2846, 2, 21.3-25.5 mm SL, collected with holotype; MZUSP 118297, 10, 23.3-25.8 mm SL, rio Contrato, tributary of rio Gurgueia, Monte Alegre do Piauí, 09³4'45.8”S $45^{\circ} 01^{\prime} 45.6^{\prime} \mathrm{W}, 22$ Jun 2006, W. Severi et al.; UFPB 7029, 45, 17.3-26.7 mm SL (2, 25.1-29.3 mm SL), rio Contrato, tributary of rio Gurgueia, Monte Alegre do Piauí,

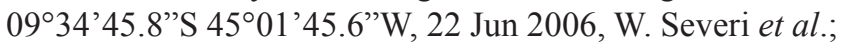
UFPB 7030, 16, 18.2-23,8 mm SL, stream tributary of rio Gurgueia, Bom Jesus, $09^{\circ} 24^{\prime} 58.3^{\prime \prime} \mathrm{S} 44^{\circ} 35^{\prime} 54.5^{\prime \prime} \mathrm{W}, 22$ Jun 2006, W. Severi et al.; UFPB 7031, 5, 22.6-26.7 mm SL (4, 24.2-26.7 mm SL), stream tributary of rio Gurgueia, Serra do Quilombo village, Bom Jesus, 09¹7'32.4'’S $4^{\circ} 29^{\prime} 59.0^{\prime \prime} \mathrm{W}, 22$ Jun 2006, W. Severi et al.; UFPB 7034, 25, 17.8-22.5 mm SL, rio Canindé, Amarante, $06^{\circ} 17^{\prime} 29.8^{\prime \prime} \mathrm{S}$ $42^{\circ} 48^{\prime} 58.0$ ”W, 1 Apr 2005; UFPB 7035, 11, 19.1-25.1 $\mathrm{mm}$ SL (2, 24.5-25.1 mm SL), riacho da Volta, Uruçuí, 07'24'16.4”S 4450'31.4”W, 31 Mar 2005, W. Severi et al.; UFPB 9715, 3, 18.4-24.8 mm SL (2, 24.7-24.8 mm SL), stream tributary of rio Gurgueia, Bom Jesus, $09^{\circ} 05^{\prime} 26.5^{\prime \prime} \mathrm{S}$ $44^{\circ} 21^{\prime} 46.4^{\prime \prime} \mathrm{W}, 22$ Jun 2006, W. Severi et al.; UFRN 1249, 4, 26.1-33.1 mm SL (2, 26.1-33.1 mm SL), rio Sambito, immediately downstream Mesa de Pedra reservoir, Valença, 06¹1'32.1”S 4159'35.3”W, 24 Mar 2013, S. Lima, T. Ramos, W. Berbel-Filho, L. Neto, S. Moraes \& A. Moraes; UFPB 11011, 2, 26.4-27.3 mm SL (2 c\&s), riacho Brejo

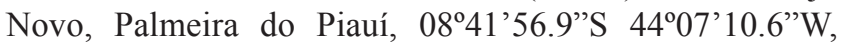
9 Nov 2011, B. Costa; UFRN 1310, 2, 20.2-24.5 mm SL (1, $24.5 \mathrm{~mm} \mathrm{SL})$, rio Sambito, downstream Mesa de Pedra reservoir, Valença, $06^{\circ} 11^{\prime} 32.1^{\prime \prime S} 41^{\circ} 59^{\prime} 35.3^{\prime \prime} \mathrm{W}, 24$ Mar 2013, S. Lima, T. Ramos, W. Berbel-Filho, L. Neto, S. Moraes \& A. Moraes. Maranhão State. UFPB 7036, 2, 29.2-30.6 mm SL, riacho Ribeirão das Facas, tributary of rio Balsas, São Raimundo das Mangabeiras, 0708’34.6”S
4542'00.5”'W, 6 Mar 2005, W. Severi et al.; UFPB 7037, 1, $29.0 \mathrm{~mm}$ SL (1), riacho Boi, tributary of rio Balsas, Sambaíba, 0657'54.3"S 45²2'38.2”W, 6 Mar 2005, W. Severi et al.; UFPB 7040, 1, $21.1 \mathrm{~mm} \mathrm{SL}$, ribeirão do Riachão, São Raimundo das Mangabeiras, 07¹3'09.6"S 45 51'02.6”'W, 6 Mar 2005, W. Severi et al.; UFPB 7041, 7, 17.2-26.4 mm SL (2, 24.9-26.5 mm SL), rio Parnaíba, Benedito Leite, $07^{\circ} 14^{\prime} 09.6^{\prime}$ 'S 44³4'24.8”W, 1 Apr 2005, W. Severi et al.

Diagnosis. Parotocinclus cabessadecuia differs from all its congeners, except $P$. bidentatus, $P$. muriaensis, $P$. dani, $P$. halbothi, P. seridoensis, and P. spilurus by possessing a vestigial or rudimentary adipose fin. The new species differs from $P$. bidentatus and $P$. muriaensis by the absence of accessory teeth on the premaxilla and dentary ( $v s$. presence of accessory dentition in $P$. bidentatus and $P$. muriaensis); by higher number of premaxillary (18-24) and dentary (16-22) teeth on each side (vs. premaxillary teeth in P. bidentatus (6-12) and P. muriaensis (10-12) and dentary in P. bidentatus (4-10) and in P. muriaensis (7-8) on each side). It differs from $P$. dani by the absence of a triangular dark blotch at the anterior base of the dorsal fin (vs. presence in P. dani); from P. halbothi, P. seridoensis and $P$. spilurus by the abdomen covered by broad dermal plates (Figs. 1, 3), especially those on the external margins, which are interspersed by small ones (vs. abdomen almost naked or covered by small, round or transversally elongated dermal plates in P. halbothi, P. seridoensis and P. spilurus). The new species differs additionally from $P$. halbothi by having a conspicuous grayish yellow stripe between the nostril and the tip of snout that results from an area with a small number of odontodes and chromatophores ( $v S$. absence of a light stripe on snout in $P$. halbothi); from $P$. seridoensis by the absence of a small area of naked skin on the snout tip without odontodes ( $v S$. snout tip totally covered by odontodes); and from P. spilurus by the pectoral girdle completely covered by large odontodes ( $v s$. pectoral girdle medially naked, supporting odontodes only laterally). 
Parotocinclus cabessadecuia is distinguished from the sympatric species $P$. cearensis by having the abdomen entirely covered by plates between the pectoral girdle and the preanal region ( $v s$. abdomen almost naked, with a single row of elongate reduced plates on each side and a group of small rounded central abdominal and preanal plates, irregularly distributed); and from $P$. haroldoi by the absence of small light spots on the head and trunk (vs. presence) and by the presence of a clear band located between the nostril and tip of snout (vs. absence).

Description. Morphometric and meristic presented on Tabs. 1-2. Maximum size of examined adults $33.2 \mathrm{~mm}$ SL. Greatest body depth at dorsal-fin origin, progressively tapering to end of caudal peduncle; body lightly depressed at region just posterior to dorsal-fin base and along anal fin; greatest body width at cleithrum, progressively tapering to end of caudal peduncle; caudal peduncle ellipsoid in cross section, not so compressed laterally. Dorsal profile convex from snout to parieto-supraoccipital tip; straight between parieto-supraoccipital and dorsal fin origin; slightly concave at dorsal-fin base, usually without odontodes or with very small ones; approximately straight from dorsal-fin origin to rudimentary adipose fin; slightly concave from this point to base of uppermost caudal-fin rays. Ventral profile approximately straight in its entire extension, except at anal-fin area and at concavity that accommodates urogenital papillae.

Head somewhat depressed, snout rounded in dorsal view; snout relatively long, around half head length; two depressions on snout in front of each nostril separated by median keel. Snout tip completely covered by conspicuous and numerous odontodes on upper portion of head arranged in ill-defined rows. Interorbital space flat or slightly convex in frontal view. Nuchal plate exposed, covered with small odontodes. Ventral surface of head naked. Pectoral girdle completely covered by odontodes except for small triangular anterior area over median suture where skin is visible in some specimens; arrector fossae small, almost meeting at midline. Except for area surrounding pelvic-fin origin, abdomen covered by broad dermal plates interspaced by small ones in T-shaped between pectoral girdle and anal region as follows: paired, laterally elongated plates in series of three to four elements; unpaired, central abdominal plates form irregular, composite series of large and elongated plates gradually substituted by rounded and smaller plates on posterior portion, reaching to or not the pre-anal shield (Fig. 3). Small naked area around anus completely surrounded by four pairs of plates.

Eye size moderate, laterodorsally positioned between snout tip and compound pterotic posterior margin; rearward positioned in head. Distance between orbit ventral margin and ventral surface of head approximately twice orbital diameter. Dorsal iris diverticulum absent in preserved specimens, but visible in live specimens.

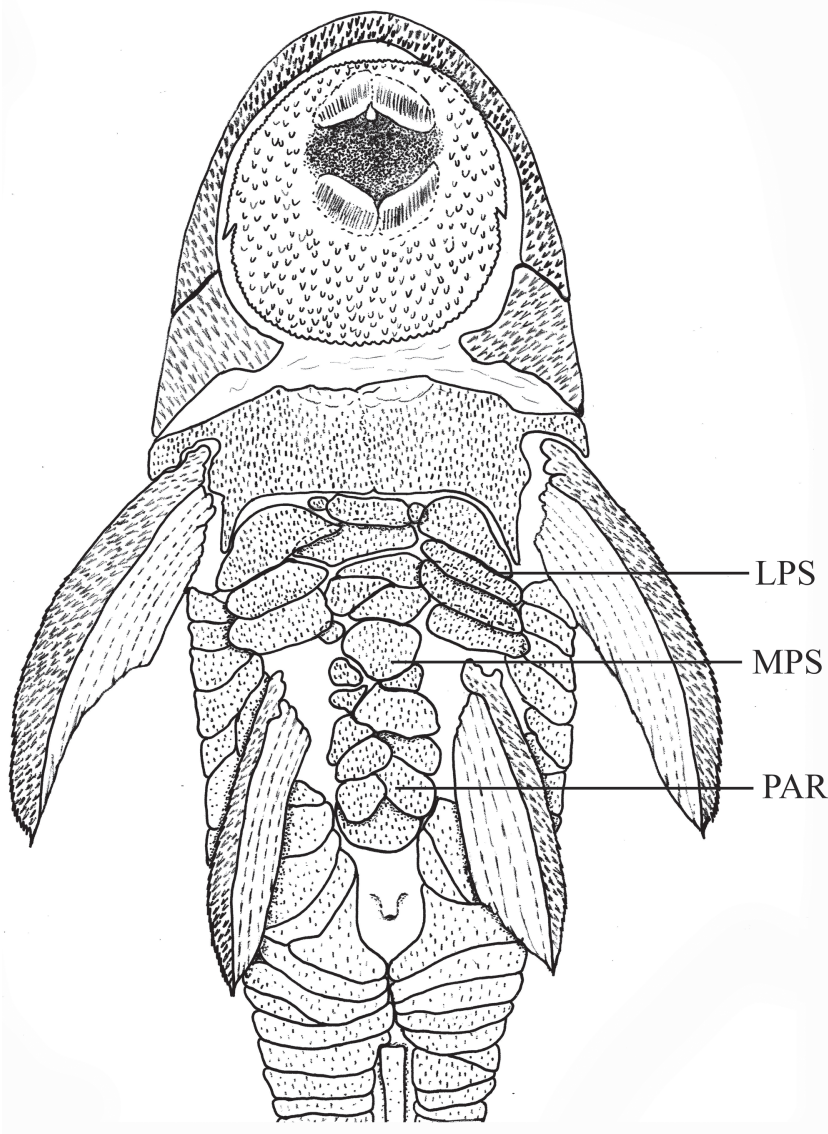

Fig. 3. Ventral view of abdominal region showing series of plates in Parotocinclus cabessadecuia, UFPB 11011 (27.3 $\mathrm{mm}$ SL), paratype. LPS, lateral plate series; MPS, median plate series; PAR, preanal region.

Tab. 1. Morphometric data of holotype and 23 paratypes of Parotocinclus cabessadecuia. Abbreviations: n, number of specimens measured; SD, standard deviation.

\begin{tabular}{|c|c|c|c|c|}
\hline & \multirow{2}{*}{ Holotype } & \multicolumn{3}{|c|}{ Paratypes } \\
\hline & & Range $(n=23)$ & Mean & SD \\
\hline Standard length $(\mathrm{mm})$ & 29.3 & $24.2-33.2$ & 26.6 & 2.2 \\
\hline \multicolumn{5}{|c|}{ Percentage of standard length } \\
\hline Body depth & 15.0 & $15.4-17.9$ & 16.6 & 0.7 \\
\hline Head length & 35.5 & $35.0-38.3$ & 36.4 & 1.1 \\
\hline Cleithral width & 25.0 & $24.1-27.3$ & 25.5 & 0.9 \\
\hline Trunk length & 15.0 & $13.9-18.2$ & 15.6 & 1.1 \\
\hline Abdominal length & 23.5 & $20.1-24.2$ & 21.4 & 0.9 \\
\hline Pectoral-fin length & 24.6 & $22.1-25.1$ & 23.6 & 0.8 \\
\hline Caudal-peduncle depth & 9.2 & $8.8-10.8$ & 9.7 & 0.5 \\
\hline Caudal-peduncle length & 32.1 & $30.8-37.7$ & 34.0 & 1.7 \\
\hline Predorsal length & 42.7 & $39.0-47.5$ & 44.6 & 2.0 \\
\hline \multicolumn{5}{|c|}{ Percentage of head length } \\
\hline Head depth & 42.3 & $41.3-47.5$ & 44.6 & 1.8 \\
\hline Snout length & 53.8 & $48.5-58.2$ & 53.1 & 2.1 \\
\hline Horizontal eye diameter & 12.5 & $11.1-16.0$ & 13.4 & 1.2 \\
\hline Interorbital width & 36.5 & $35.1-42.6$ & 38.5 & 2.0 \\
\hline
\end{tabular}


Tab. 2. Meristic data of Parotocinclus cabessadecuia.

\begin{tabular}{lccc}
\hline & \multirow{2}{*}{ Holotype } & \multicolumn{2}{c}{ Paratypes } \\
\cline { 3 - 4 } & & Range $(\mathrm{n}=23)$ & Mode \\
\hline Premaxillary teeth right & 20 & $14-24$ & 15 \\
Premaxillary teeth left & 15 & $14-24$ & 18 \\
Dentary teeth right & 15 & $14-22$ & 17 \\
Dentary teeth left & 15 & $14-22$ & 17 \\
Plates in median series & 24 & $23-25$ & 23 \\
Plates lateral to dorsal-fin base & 5 & 5 & 5 \\
Plates lateral to anal-fin base & 3 & 3 & 3 \\
Plates between anal and caudal fins & 11 & $11-12$ & 10 \\
\hline
\end{tabular}

Mouth small; oral disk roughly circular with welldeveloped papillose lips; lips almost reaching scapular bridge when depressed. Maxillary barbel short, smaller than orbital diameter. All teeth slender and asymmetrically bifid; no accessory patch of unicuspid teeth on premaxilla and dentary. Premaxillary teeth 14-24 (mode 18); dentary teeth 14-22 (17).

Dorsal fin ii,7 (spinelet, spine flexible, rays branched), its origin slightly posterior to vertical line through origin of pelvicfin base; when adpressed, dorsal fin extends through vertical posterior to anal-fin base. Dorsal-fin locking mechanism nonfunctional. Dorsal-fin spinelet present, trapezoidal, wider than dorsal-spine base. Adipose fin vestigial or rudimentary. Pectoralfin i,6; pectoral spine curved, when depressed reaching nearly half length of unbranched pelvic-fin spine; pectoral spine covered with small odontodes. Pelvic-fin rays i,5, unbranched ray curved, covered with small odontodes; surpassing anus when depressed, just anterior to anal-fin origin. Anal-fin rays i,5. Caudal fin slightly notched, emarginate, distal lobes slightly pointed, lower longer than upper; principal caudal-fin rays i,14,i. Lateral-line complete with tubes and pores visible from compound pterotic to caudal peduncle. Total vertebrae $23(2 \mathrm{c} \& \mathrm{~s})$.

Coloration in alcohol. Background color dark brown to yellowish brown. Head almost uniformly brown except for two parallel lighter lines from tip of snout to nares and for lighter patch on pineal region. Conspicuous, dark brown, longitudinal stripe extends from tip of snout to caudal peduncle or caudalfin base, along body midline, over lighter background. Lighter line along lateral line not evident in preserved specimens (Fig. 1). In laterodorsal view, four series of inconspicuous dark brown bars: on upper part of trunk at dorsal fin origin, just after dorsal-fin base, on adipose-fin origin, and near caudal-fin base. Ventral region of head and trunk whitish yellow. Dorsal-, pectoral-, pelvic- and anal-fins interradial membranes hyaline, small chromatophores scattered on fin rays. Caudal fin with relatively consistent coloration pattern of dark brown against light (translucid, whitish or yellowish) areas. These dark and light areas as diagonal dorsoventral alternate lines in most individuals (similar to pattern of living specimens).

Coloration in life. Laterodorsal background dark yellowish brown, darker in medial portion; ventrolateral background whitish to yellowish; its upper limit just above pectoral and pelvic fins. On head, yellowish brown interrupted by conspicuous grayish yellow straight line from snout to dorsal half of orbit, passing through nares. On trunk yellowish brown background interrupted by two light yellowish longitudinal lines: one narrow line along lateral line, and other wider along midline of dorsal half trunk. Irregular inconspicuous light yellow spots scattered on head and trunk. Dorsal and anal-fin rays with concentrated patch of dark chromatophores, forming irregular set of bands that alternates between dark brown and brownish yellow. Paired fins with same color pattern, but slightly lighter. Caudal fin with alternate sequences of dark and light irregular diagonal, dorsoventral stripes, more conspicuous in lower portion, starting and finishing dark (Fig. 2).

Sexual dimorphism. Males possess urogenital papilla positioned just behind anal opening and a dermal flap along posterodorsal margin of thickened first pelvic-fin ray. Adult males have a patch of the odontodes on caudal peduncle posterodorsally directed, and assembled as a cluster.

Geographical distribution. Parotocinclus cabessadecuia is only known from upper and middle rio Parnaíba basin. Asides from the main course, individuals were also collected in Gurgueia, Piauí-Canindé, Poti and Balsas tributaries (Fig. 4).

Ecological notes. In the upper stretches, Parotocinclus cabessadecuia was captured in the rio Gurgueia, the typelocality, and rio Balsas, the largest affluent on the right and left margins of the rio Parnaíba basin, respectively, both of perennial regime, under domains of the Cerrado (Fig. 5). Specimens were also caught in the rio Canindé-Piauí and rio Poti, both temporary rivers, under domains of the semiarid Caatinga (Rosa et al., 2003; Ramos et al., 2014). The typelocality had clear water and rapid current flow, rocky and sandy substrate, and variable remnant of riparian vegetation. At this sampling site, Parotocinclus cabessadecuia cooccurs with Bryconops melanurus (Bloch), Cetopsorhamdia sp., Characidium sp., Knodus victoriae (Steindachner) and Moenkhausia sanctaefilomenae (Steindachner). In the rio Sambito, sub-basin of rio Poti, the new species occurred with other species of Loricariidae: Hypostomus johnii Steindachner, Loricariichthys derbyi Fowler, Pterygoplichthys parnaibae (Weber), Ancistrus sp. and Hypostomus sp. Other cooccuring species along the known distribution were Astyanax lacustris (Lütken), Astyanax fasciatus (Cuvier), Cichlasoma sanctifranciscense Kullander, Compsura heterura Eigenmann, Crenicichla menezesi Ploeg, Hemiodus parnaguae Eigenmann \& Henn, Hoplias malabaricus (Bloch), Leporinus piau Lutken, Phenacogaster calverti (Fowler), Pimelodella parnahybae Fowler, Platydoras brachylecis Piorski, Garavello, Arce H. \& Sabaj Pérez, Potamotrygon signata Garman, Prochilodus lacustris Steindachner, Psectrogaster rhomboides Eigenmann \& Eigenmann, Schizodon rostratus (Borodin), Serrapinnus heterodon (Eigenmann), Serrasalmus rhombeus Lütken, Sternopygus macrurus (Bloch \& Schneider), Synbranchus sp., Trachelyopterus galeatus (Linnaeus) and Triportheus signatus (Garman). 

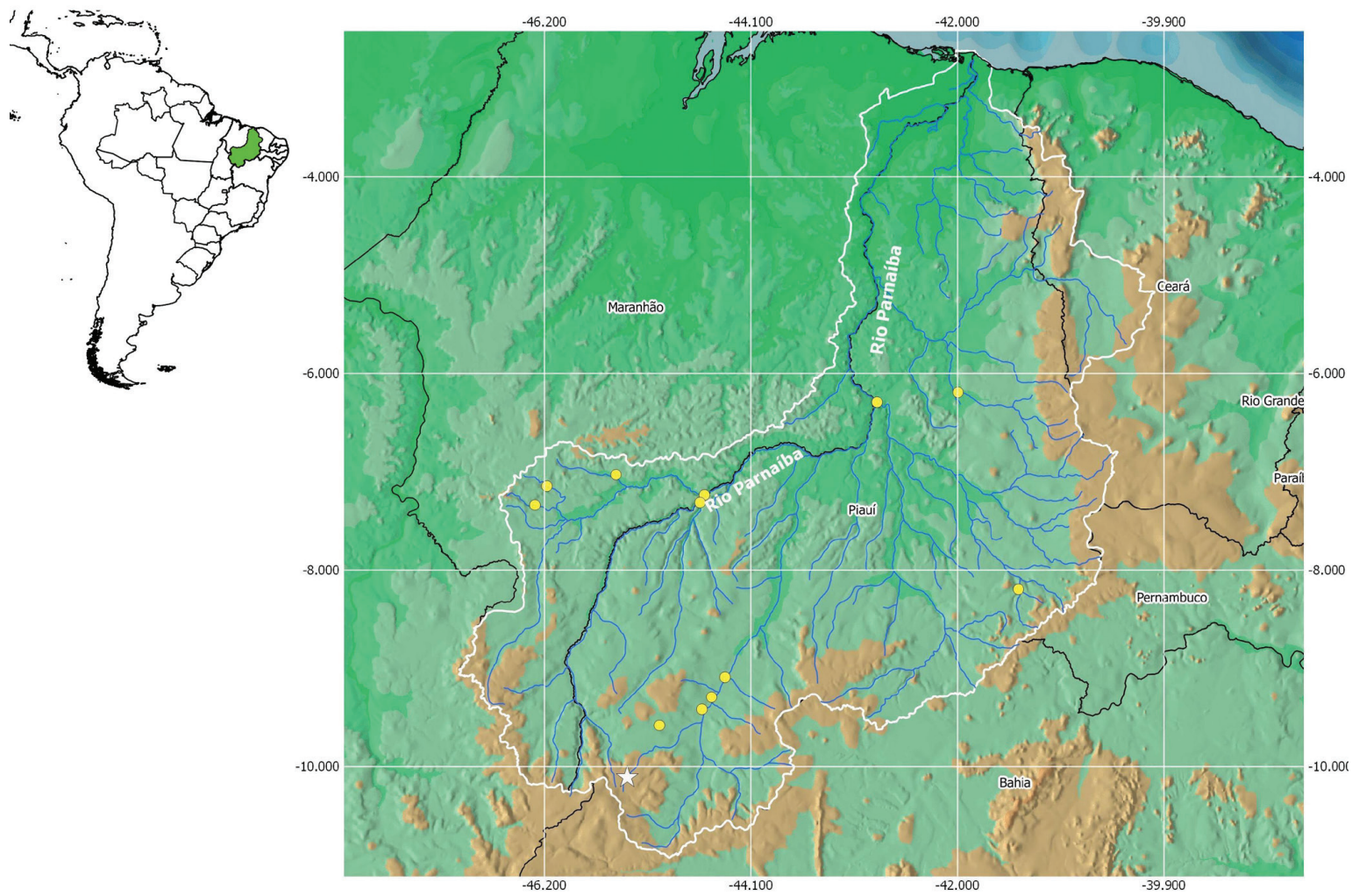

Fig. 4. Geographic distribution of Parotocinclus cabessadecuia (dots) in the rio Parnaíba basin, Northeastern Brazil. Star indicates the type-locality.

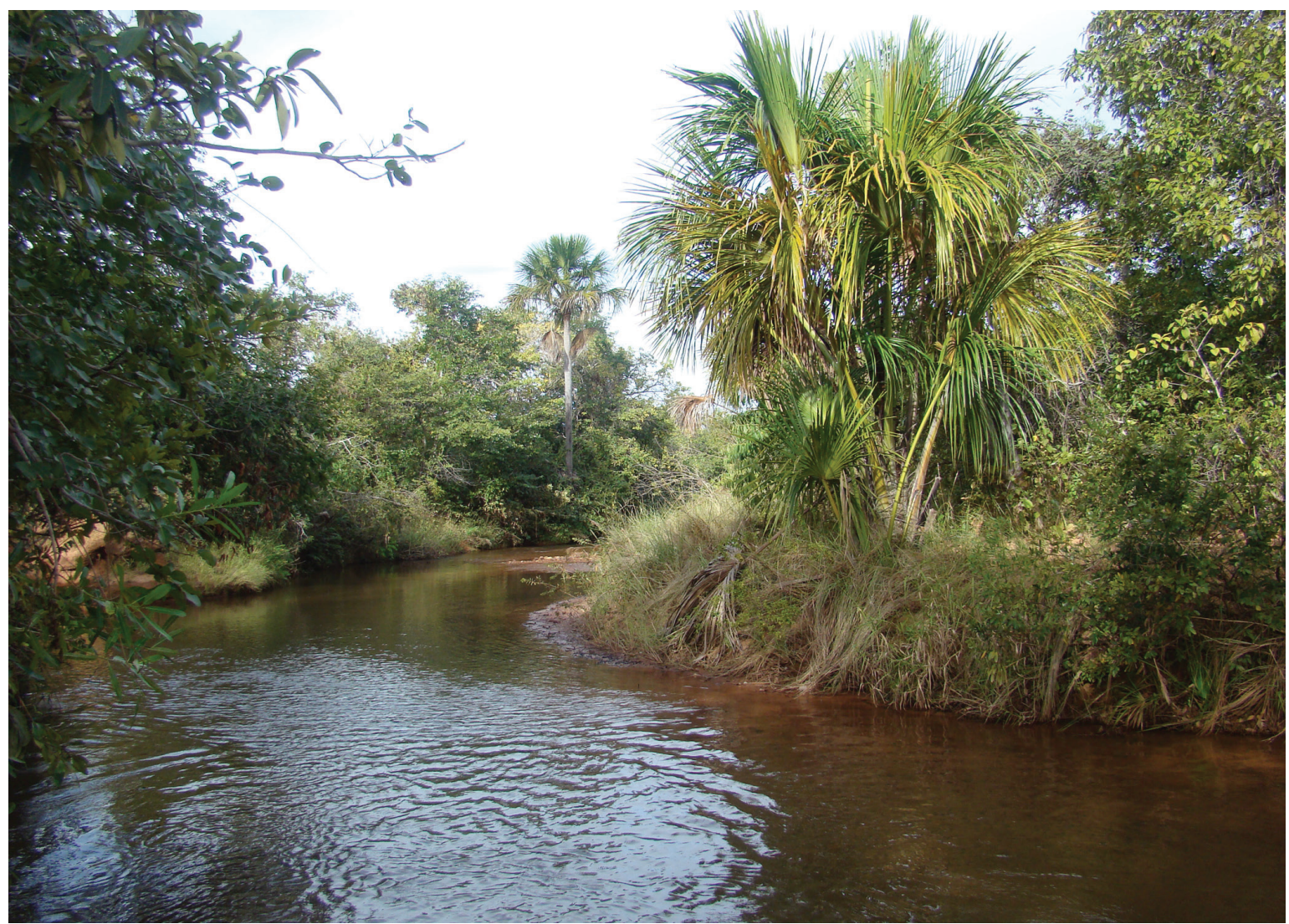

Fig. 5. Type-locality of Parotocinclus cabessadecuia, Brazil, Piauí State, São Gonçalo do Gurgueia Municipality, rio Gurgueia, rio Parnaíba basin. 
Etymology. The species epithet cabessadecuia refers to "Cabeça de Cuia", a legendary creature said to dwell on the margins of the rio Parnaíba in Piauí State, which would attack fishermen at night. "Cuia" is a hard-shelled fruit of a Bignoniacea that reminds a gourd in its shape, whose dried shell is used as bowls. The expression "gourd-head" makes reference to a large head. A noun in apposition.

Conservation status. Considering its broad geographic distribution in the rio Parnaíba basin, the high number of paratypes, and that its type-locality is in an area relatively well preserved near the Parque Nacional das Nascentes do Rio Parnaíba, a national preservation park, Parotocinclus cabessadecuia does not match any of the extinction risk categories (IUCN) and for this reason we propose that the species should be classified as Least Concern (LC) following the International Union for Conservation of Nature (IUCN) categories and criteria (IUCN Standards and Petitions Subcommittee, 2016).

Comparative material examined. A list of the comparative material is available in Ramos et al. (2013). In addition, the following material was examined: all from Brazil, Piauí, rio Parnaíba basin: Parotocinclus haroldoi: UFPB 7032, 4, 24.7-25.8 mm SL. UFPB 7039, 18, 18.1- 24.5 mm SL. UFPB 7341, 49, 20.7$26.7 \mathrm{~mm}$ SL. UFPB $7342,117,16.3-29.0 \mathrm{~mm}$ SL. UFPB 8334, 4, 13.8-24.6 mm SL. UFPB 8335, 4, 13.02-24.76 mm SL. UFPB 9719, 2, 23.1-26.7 mm SL. UFPB 9717, 3, $15.3 \mathrm{~mm}$ SL. UFPB 9723, 5, 11.7-17.7 mm SL. UFRN 1251, 1, $25.5 \mathrm{~mm}$ SL. UFRN 2218, 31 (2 c\&s), 21.2-28.7 mm SL. Parotocinclus cearensis: UFPB 9718, 51, 13.7-19.2 mm SL. UFPB 9720, 6, 15.2-17.6 mm SL. UFPB 9721, 3, 21.0-21.3 mm SL. UFPB 9722, 7, 13.5-16.3 mm SL. UFPB 9990 80, 15.7-24.2 mm SL. UFPB 9991, 1 (c\&s), $26,8 \mathrm{~mm}$ SL.

\section{Discussion}

Asides from the reduced to rudimentary adipose fin, Parotocinclus cabessadecuia is distinguishable from other northeastern Brazil species (such as P. arandai, P. bahiensis, P. cesarpintoi, P. jumbo, P. minutus and P. spilosoma) by having the abdomen entirely covered by large plates between the pectoral girdle and the preanal region (vs. abdomen provided with series of very reduced plates giving the appearance of having an almost naked abdomen). It also differs from $P$. cristatus and $P$. jimi by the abdomen provided with broad dermal plates (vs. only small dermal plates).

Garavello (1977) divided the species of Parotocinclus in the P. maculicauda and P. spilosoma groups, "according to size of denticles on the body plates and on the lower surface of the rostral margin of head". The maculicauda group is characterized by denticles that can be "large, strong and attached to the plates", and the spilosoma group characterized by denticles "small and feeble". That author reports that the proposed division is also based in a behavior associated to the presence or absence of denticles: species of the maculicauda group, which have large and strong denticles, live attached to submerged marginal vegetation, while the spilosoma group, with small and feeble denticles, live associated to benthic habit, presumably over sediment substrate. Parotocinclus cabessadecuia possess characteristics such as large and strong denticles that position it within the maculicauda group.

The non-monophyletic Parotocinclus is up-to-date composed by 30 species distributed in the cisandine neotropics drainages (Lehmann et al., 2015; Ramos et al., 2016; Roxo et al., 2016). The resolution of this systematic problem depends on the designation of new genera that reflect the relationships among the lineages currently assigned to Parotocinclus (Lehmann et al., 2014). Notwithstanding, the presence of an adipose fin is largely used to justify the practical usage of Parotocinclus, although some species with vestigial or rudimentary adipose fin (e.g. P. seridoensis, P. halbothi) were recently described (Ramos et al., 2013; Lehmann et al., 2014).

Parotocinclus haroldoi, P. cearensis, and P. cabessadecuia were recorded in the Parnaíba basin, the latter first recorded by Ramos et al. (2014) as an undescribed species (Parotocinclus sp.). Although these three species are widely distributed along the drainage, $P$. cabessadecuia was not found together with other species of Parotocinclus in the rio Parnaíba basin. In the temporal rivers of the semiarid Caatinga (MNCE), P. jumbo and P. cearensis have been recorded in sympatry with other congeneric such as $P$. seridoensis, P. spilurus and P. spilosoma (Garavello, 1977; Britski, Garavello, 2002; Ramos et al., 2013). However, a systematic review leading to a new taxonomic classification, could reveal the coexistence of different hypoptopomatine lineages. According to Roxo et al. (2014) at least two main lineages dispersed from the Amazon and Orinoco basins (composed by two undescribed species of Hisonotus and $P$. aff. spilurus) and from the Atlantic Coastal Drainages (formed by undescribed species of a new taxon, H. bocaiuva, and $P$. cf. bahianus, $P$. robustus and $P$. prata) to the São Francisco Basin and Northeastern Drainages (including MNCE and MAPE).

The description of Parotocinclus cabessadecuia reinforces the dispersion hypothesis of Parotocinclus from Amazon to Southeastern Brazil through the Northeastern basins, proposed by Garavello (1977). According to this author, the hypothesis is strengthened by the absence of record of Parotocinclus in the Paraná-Paraguay basin. No species of Parotocinclus was recorded in this last basin so far, while 16 species were recorded in the eastern Brazil coastal basins (Northeastern and Eastern regions), seven of them in the Northeastern region, which also reinforces the hypothesis of Garavello (1977).

Parotocinclus cabessadecuia is the seventh species of the genus without an adipose fin or having a reduced one. The other six species are P. spilurus and P. seridoensis both from the MNCE, $P$. bidentatus and $P$. muriaensis from the Paraíba do Sul ecoregion, and $P$. dani and $P$. habolthi from 
the Amazon-Orinoco-Guiana Core (Ramos et al., 2016; Roxo et al., 2016). The phylogenetic relationships among these species are not yet known and the evolution of the adipose fin in the Hypoptopomatinae is not yet clear.

\section{Acknowledgments}

The authors thank colleagues who participated in the fieldwork: Stéfane Ramos, Márcio Silva, Ludmila Antunes, Willian Severi, Elton França, Roney Paiva, Waldir BerbelFilho, Brisa Guimarães, Mateus Germano, Luciano BarrosNeto, Sávio Moraes, Alex Moraes. We are also grateful to Heraldo Britski for the help with identification of specimens. This study was supported by the Conselho Nacional de Desenvolvimento Científico e Tecnológico - CNPq (Process \# 483878/2013-8). Collections were made under permits 20088-3/2009 and 30532-1/2011 MMA/ICMBio/SISBIO from Ministério do Meio Ambiente/Instituto Chico Mendes de Conservação da Biodiversidade/Sistema de Autorização e Informação em Biodiversidade.

\section{References}

Britski HA, Garavello JC. Parotocinclus jumbo, a new species of the subfamily Hypoptopomatinae from northeastern Brazil (Ostariophysi: Loricariidae). Ichthyol Explor Freshwat. 2002; 13(3):279-88.

Britski HA, Garavello JC. Redescription of Parotocinclus bahiensis (Miranda-Ribeiro, 1918) (Pisces, Ostariophysi, Loricariidae). Zootaxa. 2009; 2143:59-67.

Carvalho TP, Reis RE. Four new species of Hisonotus (Siluriformes: Loricariidae) from the upper rio Uruguay, southeastern South America, with a review of the genus in the rio Uruguay basin. Zootaxa. 2009; 2113:1-40.

Garavello JC. Systematics and geographical distribution of the genus Parotocinclus Eigenmann \& Eigenmann, 1889 (Ostariophysi, Loricariidae). Arq Zool. 1977; 28(4):1-37.

Garavello JC. Three new species of Parotocinclus Eigenmann \& Eigenmann, 1889 with comments on their geographical distribution (Pisces, Loricariidae). Naturalia. 1988; 13:117-28.

Gauger MFW, Buckup PA. Two new species of Hypoptopomatinae from the rio Paraíba do Sul basin, with comments on the monophyly of Parotocinclus and the Otothyrini (Siluriformes: Loricariidae). Neotrop Ichthyol. 2005; 3(4):509-18.

Hubbs CL, Lagler KF. Fishes of the Great Lakes region. Ann Arbor: University of Michigan Press; 2006.

International Union for Conservation of Nature (IUCN). Standards and Petitions Subcommittee. Guidelines for using the IUCN Red List Categories and Criteria. Version 12 [Internet]; 2016. [updated $2016 \mathrm{Jul}$. Available from: http://www.iucnredlist. org/documents/RedListGuidelines.pdf

Lehmann PA, Braun BK, Pereira EHL, Reis RE. A new species of the Hypoptopomatinae catfish Parotocinclus (Siluriformes: Loricariidae), from the headwaters of the Rio Jequitinhonha, Brazil. Copeia. 2013; 2013(3):435-40.
Lehmann PA, Lazzarotto H, Reis RE. Parotocinclus halbothi, a new species of small armored catfish (Loricariidae: Hypoptopomatinae), from the Trombetas and Marowijne river basins, in Brazil and Suriname. Neotrop Ichthyol. 2014; 12(1):27-33.

Lehmann PA, Schvambach LJ, Reis RE. A new species of the armored catfish Parotocinclus (Loricariidae: Hypoptopomatinae), from the Amazon basin in Colombia. Neotrop Ichthyol. 2015; 13(1):47-52.

Lehmann PA. Anatomia e relações filogenéticas da família Loricariidae (Ostariophysi: Siluriformes) com ênfase na subfamília Hypoptopomatinae. [PhD Thesis]. Porto Alegre, RS: Pontifícia Universidade Católica do Rio Grande do Sul; 2006.

Martins FO, Britski HA, Langeani F. Systematics of Pseudotothyris (Loricariidae: Hypoptopomatinae). Zool J Linn Soc. 2014; 170(4):822-74.

Ramos TPA, Barros-Neto LF, Britski HA, Lima SMQ. Parotocinclus seridoensis, a new hypoptopomatine catfish (Siluriformes: Loricariidae) from the upper rio Piranhas-Açu basin, northeastern Brazil. Neotrop Ichthyol. 2013; 11(4):78796.

Ramos TPA, Lehmann PA, Barros-Neto LF, Britski HA, Lima SMQ. Redescription of the endangered hypoptopomatine catfish Parotocinclus spilurus (Fowler, 1941) (Siluriformes: Loricariidae) from the upper rio Jaguaribe basin, northeastern Brazil. Neotrop Ichthyol. 2016; 14(1):e150098.

Ramos TPA, Ramos RTC, Ramos SAQA. Ichthyofauna of the Parnaíba river Basin, Northeastern Brazil. Biota Neotrop. 2014; 14(1):1-8.

Rosa RS, Menezes NA, Britski HA, Costa WJEM, Groth F. Diversidade, padrões de distribuição e conservação dos peixes da Caatinga. In: Leal IR, Silva JMC, Tabarelli M, editores. Ecologia e Conservação da Caatinga. Recife: Editora da Universidade Federal de Pernambuco; 2003.

Roxo FF, Silva GSC, Oliveira C. Description of a new species of Parotocinclus (Siluriformes, Hypoptopomatinae) from the rio Tapajós basin. Zookeys. 2016; 634:125-36.

Roxo FF, Albert JS, Silva GSC, Zawadzki CH, Foresti F, Oliveira C. Molecular Phylogeny and Biogeographic History of the Armored Neotropical Catfish Subfamilies Hypoptopomatinae, Neoplecostominae and Otothyrinae (Siluriformes: Loricariidae). PLoS One. 2014; 9(8):e105564.

Schaefer SA. Family Loricariidae - Subfamily Hypoptopomatinae (Armored catfishes). In: Reis RE, Kullander SO, Ferraris, Jr. CJ, organizers. Checklist of the Freshwater Fishes of South and Central America. Porto Alegre: Edipucrs; 2003. p.321-329.

Taylor WR, Van Dyke GC. Revised procedures for staining and clearing small fishes and other vertebrates for bone and cartilage study. Cybium. 1985; 9(2):107-19.

Submitted August 25, 2016 Accepted March 14, 2017 by Marcelo Britto 